\title{
Implications of Adopting Public Private Partnership for Infrastructure Development in Nigeria
}

\author{
Dele S. Kadiri ${ }^{1}$, Stephen O. Ojo ${ }^{2} \&$ Godwin O. Jagboro ${ }^{1}$ \\ ${ }^{1}$ Department of Quantity Surveying, Obafemi Awolowo University, Ile-Ife, Nigeria \\ ${ }^{2}$ Department of Building, Obafemi Awolowo University, Ile-Ife, Nigeria \\ Correspondence: Dele S. Kadiri, Department of Quantity Surveying, Obafemi Awolowo University, Ile-Ife, \\ Nigeria. Tel: 234-80-3570-1241. E-mail:deleskadiri@yahoo.com
}

\author{
Received: March 16, 2015 Accepted: June 11, 2015 Online Published: November 29, 2015 \\ doi:10.5539/jsd.v8n9p169 URL: http://dx.doi.org/10.5539/jsd.v8n9p169
}

\begin{abstract}
The Infrastructure Concession Regulatory Commission (ICRC) ACT of 2005 provided the legal framework for the adoption of PPP for infrastructure development in Nigeria. This paper therefore examined the implications of the adoption of PPP for infrastructure development in Nigeria with a view to enhancing infrastructure projects delivery. The paper acknowledged the timeliness of the initiative in Nigeria owing to the wide infrastructure gap and progressive severe cut back in budgetary allocation and implementation. The paper recommended that political will, good governance and human capacity building will be required to maximise the benefits from the initiative by all stakeholders.
\end{abstract}

Keywords: adoption, implications, infrastructure development, Nigeria, public private partnership

\section{Introduction}

Infrastructure is the stock of fixed capital assets in a country, which includes roads, railways, airports, hospitals, waterways, electricity and telecommunication network (Omojuine, 1997). The term infrastructure is a generic term for basic structures and facilities that are essential to the generation of economic growth and development in modern economies. Urban infrastructures are economic social facilities which are provided by the government or by private operators, for the social and economic development of the citizenry (Adegoke et al., 2010). Adedayo and Afolayan (2012) argued that the number of tarred roads, the frequency of water and power supply, the state of environmental sanitation and the efficiency of communication system are all indices of urban development. Thus, infrastructure has been recognised as the crux of human settlement development.Mabogunje (1993) stressed that the provision of infrastructure in an extensive and continuous self-sustaining basis is a sin-qua-non for the efficiency and liveability of cities. A major drag on the pace of industrialisation development in Nigeria over the years is attributable to the poor state of infrastructure facilities (Adedayo and Afolayan, 2012).

Public-Private Partnership (PPP) is a relationship between public sector organisations and private sector investors for the purpose of procuring infrastructural facilities required in a country. According to a World Bank report (2009), PPP does not have a legal meaning and can be used to describe a variety of arrangements involving the public and private sectors working together in some way. PPP lies between privatisation (maximum involvement of the private sector) and short-term service contracts (minimum involvement of the private sector). PPPs refer to innovating methods used by the public sector to contract with the private sector who bring their capital and their ability to deliver projects on time and to budget, with the public sector retaining the responsibility to provide these services to the public in a way that benefits the public and delivers economic development and an improvement in the quality of life. PPP combines the best of both the public and private sectors: the private sector with its resources, management skills and technology, and the public sector with its regulatory actions and protection of the public interest (United Nations, 2008). According to Adegoke et al. (2010), PPPs are seen to be effective approaches for increasing public services by government in terms of quality and diversity. Babawale (2004) observed that although the provision of urban infrastructure is traditionally the preserve of government, the growing difficulty of the public in terms of financial constraints in the midst of ever increasing demand compels governments to look to the private sector for solace. 
A World Bank report (2001) claimed that the availability of infrastructure guarantees the access to resources and facilities which is one of the objectives of the Millennium Development Goals (MDGs). As observed by the Property Council of Australia (2003), there is compelling evidence that investment in public infrastructure is linked with productivity growth and economic prosperity. Failure to provide sufficient or appropriate infrastructure undermines the competitiveness of a nation and its social and environmental sustainability. Ogbuozobe (2003) noted that the Nigerian municipal authorities have been incapacitated in their efforts at providing urban services and can no longer cope with the social, political, economic and psychological problems posed by rapid urbanization. Mabogunje (2002) cited in Olawale (2004) affirmed that investment in public utilities and infrastructure has failed to keep pace with the accelerated growth rate of the urban population as evident in Lagos metropolis. To meet the needs of the demanding population, urban infrastructure must be provided, maintained and be in good performance conditions.

The level of basic infrastructure -particularly roads, transportation and water- is seen as a defining characteristic of poverty in Nigeria (Narayan, 2000). Amis and Kumar (2000) therefore argued that infrastructure helps individuals to cope with the different dimensions of poverty. Wherever people are deprived of basic infrastructure, the result is impoverishment. Thus, there is a positive correlation between a developed urban infrastructure and economic growth and trade coupled with significant reduction in poverty and inequality. It was therefore against the foregoing background that this paper examined the implications of the adoption of PPP for infrastructure development in Nigeria with a view to enhancing its effectiveness for infrastructure project delivery.

\section{InfrastructureProcurement Models}

For many years, the public sector has traditionally financed and operated infrastructure projects using resources from taxes and various levies like fuel taxes and road user charges amongst others. Ashworth and Hogg (2007) classified infrastructure procurement models into two broad categories of traditional and non-traditional procurement models. The traditional model is that in which the three sequential phases of design, bid and build are separated (Babatunde et al., 2010). According to Kadiri and Odusami (2003), the variants of the traditional model include the use of the Traditional Contract, Labour-only Contract, Management Contracting, and Direct Labour procurement systems. The modus operandi of this model include the provision of funds by the clients (government), the production of tender documents by consultants who are engaged by the clients, collection of documents and submission of tenders by contractors one of whom is awarded the contract, and the physical construction of the project by the successful contractor under the management/administration of the professional consultants engaged by the clients. Public projects under the traditional procurement model were procured using budgetary allocations, inter-government transfers, grants and donor funds. However, Falowo (2008) affirmed that their funding profile was $70 \%$ public budget and soft loans and $30 \%$ private/multilateral infrastructure investments.

Ashworth and Hogg (2007) opined that the non-conventional procurement model include the use of Design and Build and Public-Private Partnership procurement arrangements. Apart from the constraints of availability of funds, the need for the non-conventional procurement model was due to the adversarial tendencies of the traditional procurement model. That is, because of the fact that the participants operated from under different roofs, they tended to harbour professional bias toward their roles as against a mutually beneficial relationship obtainable when participants operate from under the same roof.

According to the World Bank (2009), the varieties of PPP are build, operate and transfer (BOT); design, build, finance and operate (DBFO) when the asset is returned to the public sector; and build, operate and own (BOO) when the asset is not returned. The various classifications and features of PPP models are shown in Table 1 and Figures 1 and 2. PPP may be concession-based or availability-based. In concession-based PPP, the public authority grants a private party the right to design, build, finance and operate a public asset for a fixed period of between 25 and 30 years after which the asset reverts to the public authority. The private sector recoups its investment, operating and financing costs and its profit by charging members of the public a user fee (for example, a toll).

A franchise is a subset of concession-based PPP in which the private sector takes over existing public infrastructure, operating and maintaining it under a fixed-term contract, often with an obligation to upgrade it. 
Table 1. Classification of PPP models

\begin{tabular}{|c|c|c|c|c|c|}
\hline Broad Category & $\begin{array}{l}\text { Main } \\
\text { Variants }\end{array}$ & $\begin{array}{l}\text { Ownership of } \\
\text { capital assets }\end{array}$ & $\begin{array}{l}\text { Responsibility } \\
\text { of investment }\end{array}$ & $\begin{array}{l}\text { Assumption } \\
\text { of risk }\end{array}$ & $\begin{array}{l}\text { Duration } \\
\text { of contract } \\
\text { (years) }\end{array}$ \\
\hline \multirow{3}{*}{$\begin{array}{l}\text { Supply } \\
\text { management } \\
\text { contract }\end{array}$} & Outsourcing & Public & Public & Public & $1-3$ \\
\hline & $\begin{array}{l}\text { Maintenance } \\
\text { management }\end{array}$ & Public & Public/Private & Private/Public & $3-5$ \\
\hline & $\begin{array}{l}\text { Operational } \\
\text { management }\end{array}$ & Public & Public & Public & $3-5$ \\
\hline Turnkey & & Public & Public & Public/Private & $1-3$ \\
\hline \multirow{2}{*}{ Aftermage/Lease } & Aftermages & Public & Public & Public/Private & $5-20$ \\
\hline & Lease & Public & Public & Public/Private & $5-20$ \\
\hline \multirow{2}{*}{ Concessions } & Franchise & Public/Private & Public/Private & Public/Private & $3-10$ \\
\hline & BOT & Public/Private & Public/Private & Public/Private & $15-30$ \\
\hline \multirow{3}{*}{$\begin{array}{l}\text { Private ownership } \\
\text { of assets and PFI } \\
\text { type }\end{array}$} & $\mathrm{BOO} / \mathrm{DBFO}$ & Private & Private & Private & Indefinite \\
\hline & PFI & Public/Private & Private & Public/Private & $10-20$ \\
\hline & Divestiture & Private & Private & Private & Indefinite \\
\hline
\end{tabular}

Source: Quium (2011)

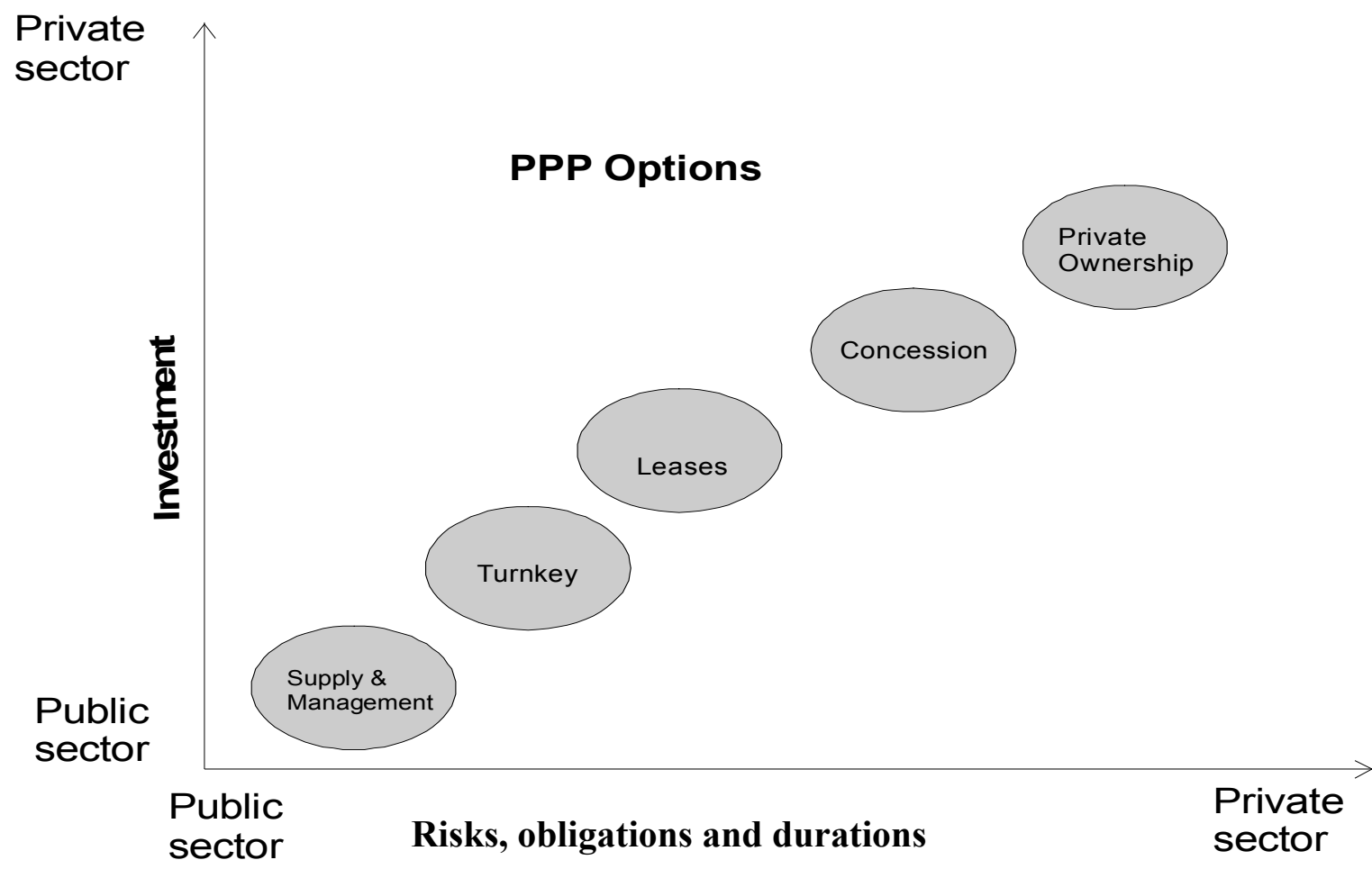

Figure1. Basic features of PPP models

Source: Quium (2011) 


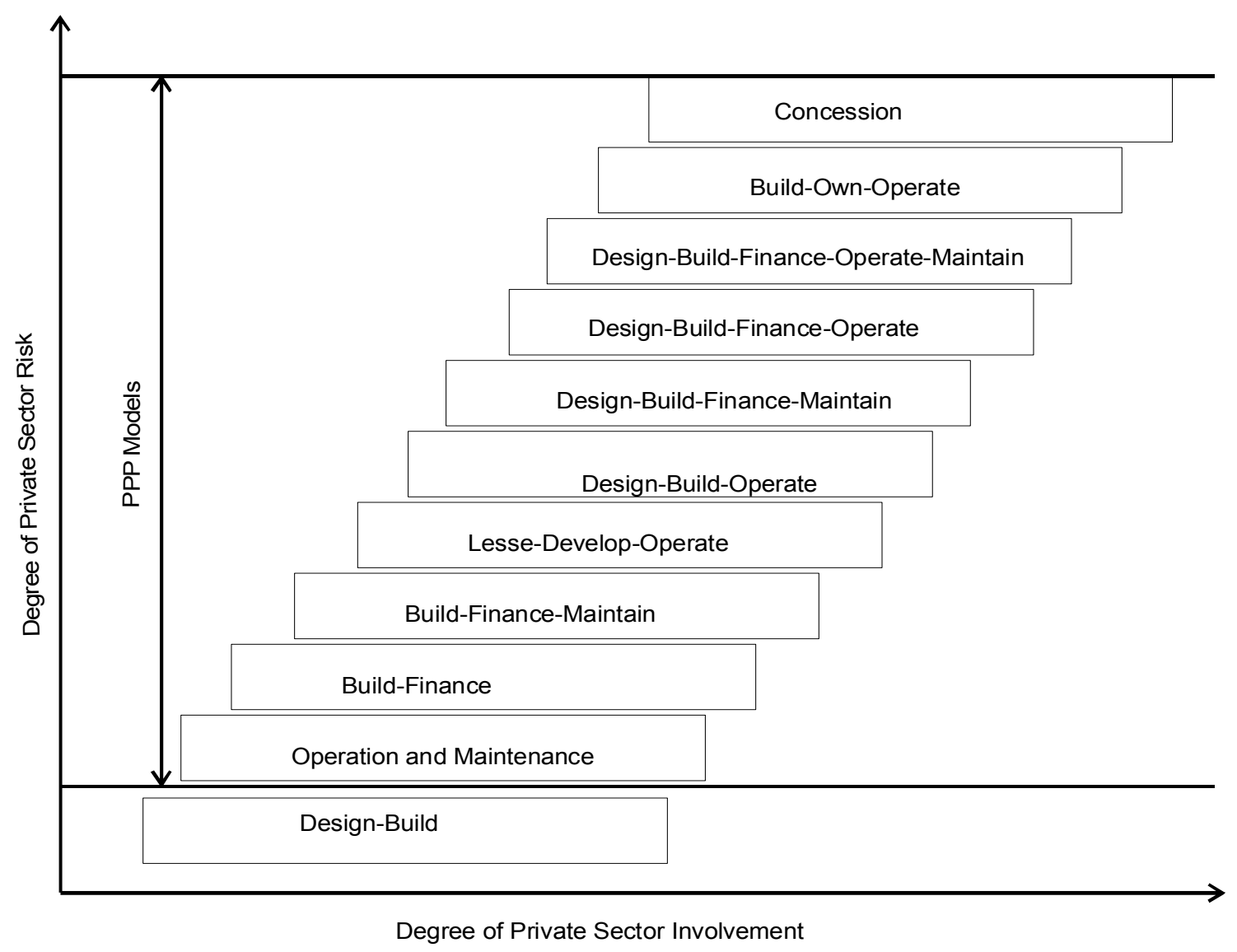

Figure 2. The scale of PPPs

Source: The Canadian Council for PPPs

The main dividing line between concession and franchise is in terms of high and low level of initial investment respectively. Availability-based PPP is one in which the public authority, and not the user, makes payments to the private party as, when, and to the extent the asset is made available. Hence, the demand or usage risk remains with the public authority.

Under a PPP arrangement, the private sector usually agrees to undertake the following: design and build or upgrade the public infrastructure; assumes substantial financial, technical, and operational risks; receive financial return through payments over the life of the contracts from users, from the public sector, or from a combination of the two; and return the infrastructure to public sector ownership at the end of the contract (in some cases, the private sector may retain ownership of the asset).

A United Nation's report (2008) claimed that PPPs have emerged as an important tool to bridge the infrastructure deficit which can provide a number of specific benefits to the public including better value (lower cost, higher levels of service, and reduced risks); access to capital; certainty of outcomes; off-balance sheet borrowing; and innovation. According to Quium (2011), PPPs are not without their limitations. For example, not all projects are feasible (for political, legal, and commercial reasons); the private sector may not take interest in a project due to perceived high risk; a PPP project may be more costly unless additional costs (due to higher transaction and financing costs) can be off-set through efficiency gains; change in operation and management control of an infrastructural asset may not be sufficient to improve its economic performance unless other necessary conditions are met. These conditions include appropriate sector and market reform, and a change in operational and management practices of infrastructure operation; and the success of PPPs depend on regulatory efficiency. The key phases and stages of development of PPP process are illustrated in Table 2 and Figure 3. 
Table 2. Three stages of PPP development

\begin{tabular}{|c|c|c|}
\hline Stage One & Stage Two & Stage Three \\
\hline 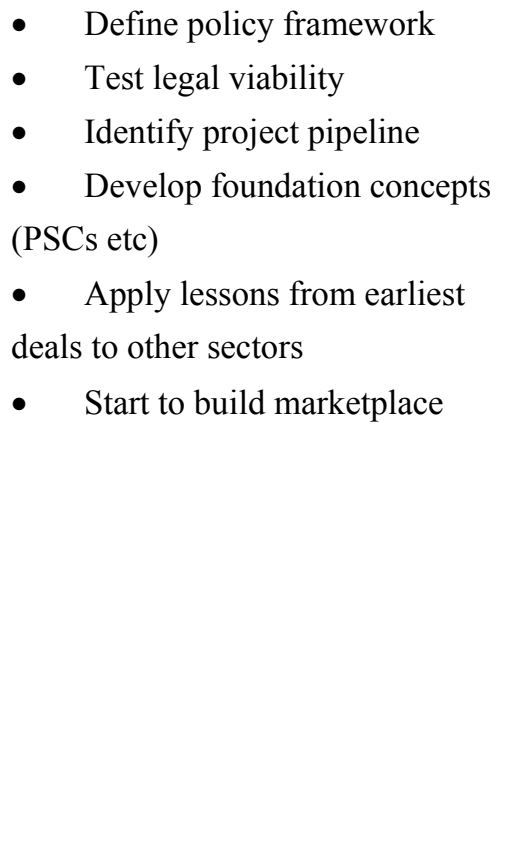 & $\begin{array}{l}\text { - } \quad \text { Introduce legislative reform } \\
\text { - } \quad \text { Publish policy and practice } \\
\text { guidelines } \\
\text { - } \quad \text { Establish dedicated PPP units } \\
\text { - } \quad \text { Refine PPP delivery models } \\
\text { - } \quad \text { Continue to foster } \\
\text { marketplace } \\
\text { - } \quad \text { Expand project pipeline and } \\
\text { extend to new sectors } \\
\text { - } \quad \text { Leverage new sources of } \\
\text { funds. }\end{array}$ & $\begin{array}{l}\text { - } \quad \text { Fully defined, comprehensive } \\
\text { “system” established. } \\
\text { - } \quad \text { Legal impediments removed. } \\
\text { - } \quad \text { PPP models refined and } \\
\text { reproduced } \\
\text { - } \quad \text { Sophisticated risk allocation } \\
\text { - } \quad \text { Committed deal flow } \\
\text { - } \quad \text { Long-term political consensus } \\
\text { - } \quad \text { Use of full-range of funding } \\
\text { sources. } \\
\text { - } \quad \text { Thriving infrastructure } \\
\text { investment market involving } \\
\text { pension funds and private equity } \\
\text { funds. } \\
\text { - } \quad \text { Well-trained civil service } \\
\text { utilises PPP experiences }\end{array}$ \\
\hline
\end{tabular}

Source: United Nations Guide Book (2008)
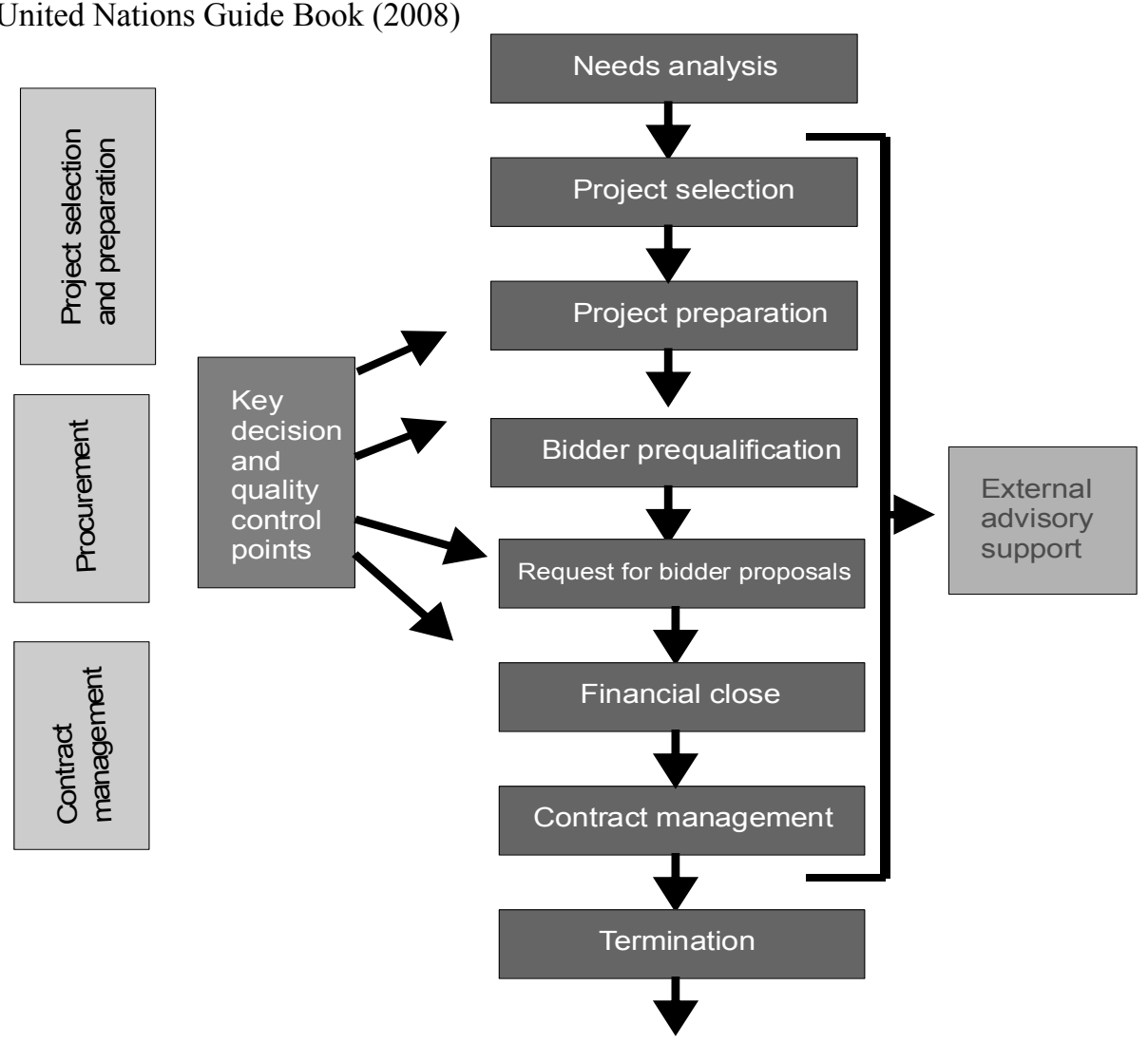

Figure 3. Key phases of PPP project process

Source: World Bank Data Base (2009)

\section{Adoption of PPP in Nigeria}

PPP is a global trend in infrastructure provision. According to a World Bank report, other regions of the 
developing world have moved ahead of Africa in involving the private sector in infrastructure development as shown in Table 3. Akintoye (2015) agreed that Nigeria occupies the low position in the adoption of PPP alongside Finland, Switzerland, Japan, and Turkey. Similarly, Belgium, Malaysia, Indonesia, China, Greece, Italy and Canada occupy the medium position; while the top position is occupied by Portugal, Ireland, UK, Australia, India and USA. Moreover, the position of the United Nations' guidebook on market maturity curve showed that the UK, Australia and Ireland in that order are the most sophisticated. Spain, France, Canada, USA, Japan and Netherlands occupy medium level of sophistication. South Africa, Belgium, Denmark, Mexico, Finland and Brazil, amongst others, still operate at a low level of sophistication with regard to market development. The guidebook however envisaged the potential of Portugal to leap frog from the level of medium sophistication to high level of market development. Public infrastructure projects require high capital outlay to procure. Traditionally, they are procured through government budgets. Opawole et al. (2011), observed that there has been a huge deficiency in infrastructure provision in Nigeria over the years owing to poor budgetary allocation and implementation, lack of political will by governments, low or non-existent high level human capacity amongst others. Consequently, public-private alliance financing initiatives have to be brought into the mainstream of infrastructure provision in Nigeria.

Table 3. Number and values of PPPs by regions (1996-2006)

\begin{tabular}{ccl}
\hline Value (\$ Million) & Number of Projects & \multicolumn{1}{c}{ Regions } \\
\hline 158,841 & 847 & East Asian and Pacific \\
119,360 & 419 & Europe and Central Asia \\
287,007 & 894 & Latin America and the Caribbean \\
60,550 & 267 & South Asia \\
8,949 & 53 & Middle East \\
40,685 & 289 & Sub-Saharan Africa \\
38,190 & 47 & North Africa \\
\hline
\end{tabular}

Source: World Bank Data base (2009)

Quium (2011) contended that governments in most developing countries face the challenge to meet the growing demands for new and better infrastructure services due to funding constraints from the traditional sources. They have found that the private sector is an attractive alternative to increase and improve the supply of infrastructural services. PPPs have thus become attractive to governments as an off-budget mechanism for infrastructure development because of a number of reasons. These include the fact that they can enhance the supply of much-needed infrastructure services, they may not require any immediate cash spending, and they provide relief from the burden of the costs of design and construction. The others are they allow transfer of many project risks to the private sector, and promise better project design, choice of technology, construction, operation and service delivery (Quium, 2011).

Adedayo and Afolayan (2012), asserted that the challenges of infrastructure provision have been recognised in Nigeria and have been listed as a cornerstone component for the realisation of vision: 20:2020 goals as well as the Millennium Development Goals (MDGs) target. Infrastructure needs according to Nigeria's National Economic Empowerment and Development Strategy (NEEDS) (2004), cut across sectors and is central to economic development. According to Adegoke et al. (2010), recent disparity between the capacity to generate resources and the demand for new facilities has forced governments to look for new funding methods and sources in the form of Public-Private Partnership arrangements. Thus, there is compelling evidence that Nigeria has come to terms with procurement of public infrastructure via PPP arrangements. In fact, the Nigerian market is increasingly being muted as the 'infrastructure investor's destination of choice'.Ngbenwelu (2012) observed that the awakening of the benefits of PPPs commenced in Nigeria around 2002, but not much was done until 2005 when government established the Infrastructure Concession Regulatory Commission (ICRC) Act 2005 that provided for the establishment of ICRC and other related matters. The intention was to put in place an effective framework for PPPs in Nigeria. The commission was inaugurated in 2008 and has since developed the National Policy on PPPs to provide clear and consistent processes and procedures for all aspects of PPPs in Nigeria.

Currently, a number of infrastructures have been executed using PPPs in Nigeria. They include Lekki-Epe 
express way and Lagos State Blue Line, while the Lekki-Epe International Airport and Deans hanger Projects Limited (a N29.63bn project finance facility) and Akute Bridge are still ongoing all in Lagos State (Ngbenwelu, 2012). Similarly, Sanni (2012) claimed that PPPs have been used in the execution of a number of infrastructures in Lagos State. These include the domestic wing of Muritala Mohammed Airport General Aviation terminal II, Lekki infrastructure project, Akute power plant project, Lagos Island power projects, Bola Tinubu medical diagnostic centre (Lasucom,Ikeja), Tejuoso market, Isolo general hospital mortuary, and Ikeja Independent Power Project. Quite a number of PPP deals are in the pipeline as shown in Table 4.

Table 4. Nigeria's select PPP deals in the pipeline

\begin{tabular}{|c|c|c|c|c|}
\hline Project & Overview & Status & $\begin{array}{l}\text { Estimated } \\
\text { cost }\end{array}$ & $\begin{array}{l}\text { Revenue } \\
\text { model }\end{array}$ \\
\hline Abuja-Kaduna-Kano & $\begin{array}{l}\text { Rehabilitation and upgrade } \\
\text { of } 210 \text { kilometers road }\end{array}$ & $\begin{array}{l}\text { OBC and EIA completed, } \\
\text { FBC to commence shortly }\end{array}$ & $\begin{array}{l}\text { N47.250bn } \\
\text { (US\$295m) }\end{array}$ & Tolling \\
\hline 2nd Niger Bridge & $\begin{array}{l}\text { Construction of new bridge } \\
\text { to alleviate traffic } \\
\text { congestion }\end{array}$ & $\begin{array}{ll}\text { EOI placed for } \\
\text { concessionaires } & \text { and } \\
\text { technical advisor } & \end{array}$ & $\begin{array}{l}\$ 60.06 \mathrm{bn} \\
(\mathrm{US} \$ 378 \mathrm{~m})\end{array}$ & Tolling \\
\hline Onne Port IPP & $\begin{array}{l}\text { Construction of an IPP to } \\
\text { assist with the smooth } \\
\text { operations of the port }\end{array}$ & TBA & US\$111m & $\begin{array}{l}\text { User } \\
\text { charges }\end{array}$ \\
\hline Lagos Port IPP & $\begin{array}{l}\text { Construction of an IPP to } \\
\text { assist with the smooth } \\
\text { operations of the port }\end{array}$ & TBA & $\begin{array}{l}N 5.7 \mathrm{bn} \\
(\mathrm{US} \$ 35 \mathrm{~m})\end{array}$ & $\begin{array}{l}\text { User } \\
\text { charges }\end{array}$ \\
\hline $\begin{array}{l}\text { Abuja Light Rail I } \\
\text { and II }\end{array}$ & $\begin{array}{l}\text { New railway in the Federal } \\
\text { Capital Territory to address } \\
\text { increasing traffic } \\
\text { congestion }\end{array}$ & $\begin{array}{l}\text { Transaction advisor to be } \\
\text { appointed and long-term } \\
\text { funding being explored }\end{array}$ & TBA & $\begin{array}{l}\text { User } \\
\text { charges }\end{array}$ \\
\hline
\end{tabular}

Source: Mgbenwelu (2012)

The construction of the approximately 50 kilometre Lekki- Epe expressway which commenced in 2008 between the Lagos State government and Lekki Concession Company (the Concessionaire) is claimed by Ngbenwelu (2012) to be the first West Africa's PPP toll road. The project financing would not have been possible in the absence of long-term debt which example is hoped to be replicated on the infrastructure transactions in Nigeria. Ngbenwelu (2012) affirmed that there is no doubt that the PPP and privatisation process in Nigeria is moving full steam ahead with governments (both at State and Federal levels) demonstrating tangible commitments towards these important initiatives. What remain to be seen, and which will indeed impact further confidence into the market are government's adherence to agreed time tables and implementation plans and the manner in which the projects achieve completion and are subsequently managed.

\section{Implications of the Adoption of PPP in Nigeria}

PPPs are still in their infancy in most developing countries and the lack of processes, procedures, and enabling institutions, i.e. governance, is the main barrier to extending their use (United Nations, 2008). The lack of good governance and well performing institutions in many countries are reflected in several things such as the protracted length of negotiations between public and private partners, the slowness in reaching closures, the lack of flexibility in risk-sharing, and the cancellation of many projects with all the resultant waste. The challenge is not just to create new institutions but also to develop the public expertise to administer projects. PPPs demand a strong public sector which is able to adopt a new role with new abilities. Strong PPP systems require managers who are skilled in negotiation, contract management and risk analysis.

However, from the Nigerian experience of its adoption, the PPP has not been without problems and challenges ranging from project governance, through high level human capacity to land acquisition encumbrances amongst 
others. Despite avowed advantages, recent international PPP experiences have shown that extensive planning actions are required in order to manage the risk of PPP failure (World Bank, 1999; Menckhoff and Zegras, 1999; Fisher and Babbar, 1996; Shaw et al; 1996). In fact, according to Quium (2011), without institutional arrangement and resource materials, public officials face difficulty in project development and implementation and the general public can have many misunderstandings about PPPs.

There is no doubt that Nigeria stands to gain from the adoption of PPP for infrastructure development. For sure, it will lead to better living standards for the citizenry as governments will have better use of tax payers' money. Moreover, it will ensure continuous business for the well organised contracting firms with attendant creation of more job opportunities and human capacity building. It will also lead to improvement in environmental sanitation, community involvement and sustainable development.

Akintoye (2015) contended that governments of developing countries do not possess the necessary management skills to set up and follow up the complexity of PPP contracts and processes. Consequently, for Nigeria to derive maximum benefits from the adoption of PPP, there is the need to ensure stronger public institutions both in terms of political will and human capacity building. Highly skilled man power will ensure that there is ability to know which projects are feasible to embark upon since projects with high risks may be rejected by private sector investors. Skilled public sector representatives will not only be able to negotiate better with private sector investors but also be better equipped to advise on the selection of projects on the basis of value for money rather than on off- balance sheet attraction. Political will will ensure appropriate sector and market reforms (regulatory efficiency) necessary for economic performance and changes in operational and management practices.

Regulatory efficiency will by extension ensure the continuity of PPP contracts even when there is a change of government. There will also be commitment to good project governance in terms of adherence to agreed time tables and implementation plans for execution and management. Thus, at the end of a PPP contract, it is hoped that public officials would have developed sufficient capacity to take over the management of the facilities where there is positive attitudinal change. Otherwise, there would have to be a re-negotiation with the concessionaire for the continued management of the facilities. By and large, there is the need to provide alternatives for citizens who may not be able to afford the high tariffs on tolled facilities in line with global best practice. In some countries, alternative routes are provided for poor road users who cannot pay for tolled roads. It should however be noted that these alternative routes can also be longer and more stressful.

\section{Conclusion}

The paper examined the implications of the adoption of Public Private Partnership for infrastructure development in Nigeria with a view to enhancing infrastructure project delivery. Key concepts in the title were defined such as infrastructure and PPP. The role of infrastructure development in improving a nation's living standard and reduction of poverty and inequality amongst the citizens were acknowledged. The paper observed the continuous threat to the provision of public infrastructures in Nigeria stemming from population explosion of Nigeria's metropolis and severe cut back in budgetary allocations by governments and argued that the adoption of PPP by Nigeria is a mandatory alternative in line with current global practice. While acknowledging the giant stride of Nigeria in putting in place a legal framework for its operation since 2008, the paper is of the opinion that much still need to be done in the areas of human capacity building and good governance for sustainability of the initiative. Consequently, the paper advocates for strong institutions so that the initiative will be mutually beneficial to both the public and private sectors alike.

\section{References}

Adedayo, A., \& Afolayan, G. P. (2012). Implications of community infrastructure provision in the development of medium-sized towns in Kwara State, Nigeria.

Adegoke, O. J., Olaleye, A., \& Araloyin, F. M. (2010). An examination of the need for Public-private partnership in the provision of urban infrastructure in Lagos metropolis. Ife Journal of Environmental Design and Management, 4(1), 66-82.

Akintoye, A. (2015). PPP: Variations and Country Contexts. Keynote address 1 at the Faculty of Environmental Design and Management international conference (EDMIC2015) at Obafemi Awolowo University, Ile-Ife, Nigeria, March.

Amis, D., \& Kumar, S. (2000). Urban economic growth, infrastructure and poverty in India: Lessons from Visakhapatnam. Environment and Urbanisation, 12(1). http://dx.doi.org/10.1177/095624780001200113

Ashworth, A., \& Hogg, K. (2007). Willis's Practice and Procedure for Quantity Surveyor. Oxford: Blackwell Publishing. 
Babatunde, S. O., Babalola, O., \& Opawole, A. (2010, May). Financial probity in public projects procurements and millennium development goals. Ife Journal of Environmental Design and Management, 4.

Babawale, G. K. (2004). Sustainable Urban infrastructure delivery in Nigeria: The role of the private sector and the community-based organisation. Paper presented at the $34^{\text {th }}$ Annual Conference of the Nigerian Institution of Estate Surveyors and Valuers, 2004.

Fisher, G., \& Babber, S. (1996). Private financing of toll roads. RMC discussions Paper Series 117. Washington DC: World Bank.

Kadiri, D.S., \& Odusami, K.T. (2003, July/September). Comparative study of time and cost performance of direct labour and Labour-only procurementsystems in Nigeria. Journal of the Nigerian Institute of Quantity Surveyors, 44(3).

Mabogunje, A. L. (1993). Infrastructure: the crux of modern Urban Development. Urban age 1 (3):3.

Menckhoff, G., \& Zegras, C. (1999). Experiences and issues in urban infrastructure concessions. Proceedings of International Road Federation (IRF) symposiums. Hanoi, Vietnam.

Mgbenwelu, P. O. (2012). Privatisation and public-private partnerships in Nigeria. FBN Capital Limited, Lagos: 67-72.

Narayan, D. (2000). Voices of the poor: can anyone hear us? New York: Oxford University Press. http://dx.doi.org/10.1596/0-1952-1601-6

Nigeria: National Economic Empowerment and Development Strategies (NEEDS).(2004).

Ogbuozobe, J. E. (2003). The imperatives of Public-Private Partnership.In Y.Fahwehinmi (Ed.),Urban Finance and Infrastructural Development in Nigeria. Ibadan: Institute of Land Economics and Atlantic Books.

Omojuine, E. O. (1997). Creating infrastructure for sustainable economic growth in Nigeria. The Estate Surveyors and Valuers, (1).

Opawole, A., Jagboro, G. O., \& Babatunde, S. O. (2011). Factors influencing the implementation of public infrastructure in Nigeria. Global Journal of Researches in Engineering, 11(6), 29-38.

Property Manuel of Australia. (2003). Urban infrastructure - Approaches compared. Allens Consulting Group.Retrieved from http://www.Allenconsult.com.au

Quium, A. (2011). A quidebook on public-private Partnership in infrastructure. Bangkok: United Nations.

Sanni, A. G. (2012). Evaluation of risks associated with concession contracts in Lagos State, Nigeria. Unpublished M.Sc. Thesis, Department of Quantity Surveying, Obafemi Awolowo University, Ile-Ife, Nigeria.

Seeley, I. H. (1997). Quantity Surveying Practice (2nd ed.). New York: Palgrave Macmillan. http://dx.doi.org/10.1007/978-1-349-14402-0

Shaw, N., Kenneth, M. G., \& Lou, T. (1996). Concessions in transport. TWU-27, TWUTD, Washington DC: World Bank.

United Nations. (2008). Guidebook on promoting good governance in Public-Private Partnerships. Geneva.

World Bank. (2009). Attracting investors for African Public-Private Partnerships: A project preparation guide. Washington.

\section{Copyrights}

Copyright for this article is retained by the author(s), with first publication rights granted to the journal.

This is an open-access article distributed under the terms and conditions of the Creative Commons Attribution license (http://creativecommons.org/licenses/by/3.0/). 